\title{
Technical efficiency of smallholder malt barley producers in Tiyo district (Ethiopia)
}

\author{
Yadeta Bekele, Guta Regasa
}

\author{
Jimma University \\ P.O. Box 307, Cluj-Napoca, Federal Democratic Republic of Ethiopia
}

This study analyzed the determinants of technical efficiency of smallholder malt barley producers and estimated their technical efficiency in Tiyo district of Arsi zone, Ethiopia. Data were obtained from 162 randomly selected malt barley farmers. Descriptive statistics and the translog functional form of the production function simultaneously with single stage estimation approach were used to estimate the production of barley output and technical inefficiency factors. The study revealed that the average technical efficiency of the farmers in the production of malt barley is $71 \%$. This reveals that there exists a possibility to increase the level of malt barley yield by $29 \%$ utilizing the existing local technical knowledge of efficient farmers. This further implies that it is possible to produce the same output by reducing current input utilization by $29 \%$. The discrepancy ratio $(\gamma)$, which estimates the relative deviation of output from the frontier level due to inefficiency, was about $61 \%$. This implies that about $62 \%$ of the variation in malt barley production among the sample farmers was credited to technical inefficiency while, the remaining $38 \%$ comes due to factors outside the control of farmers. The maximum likelihood parameter estimates showed that malt barley yield was significantly influenced by the amount of fertilizers (DAP and UREA), number of oxen, labour, malt barley seed, herbicide usage and land allocated for malt barley. The stochastic production frontier model shows that experience, education status, number of oxen, land size, and extension contact significantly affected technical inefficiency of malt barley production. Therefore, attention should be given to improve the less efficient farmers following the practices of relatively efficient farmers in the area. On top of this, policies and strategies of the government should give due focus for the determinants of technical inefficiencies in malt barley production.

Keywords: Cobb - Douglas; malt barley; stochastic frontier; technical efficiency

\section{Introduction}

Agriculture still remains to be the major driver of growth of the Ethiopian economy. This sector contributes to the livelihoods of the community by offering inputs, supplying foods, source of foreign exchange, creating employment opportunities, rising gross domestic product (Ntabakirabose, 2017). It shares about 36\% of the GDP, gives employment opportunities to more than $73 \%$ of total popula- 
tion, fetches about $70 \%$ of the foreign exchange earnings of the country and $70 \%$ raw materials for the industries in the country (UNDP, 2018).

Ethiopia is the second largest barley producer in Africa (sharing about 25\% of the total barley production in the continent), next to Morocco and ranked $21^{\text {st }}$ in the world (FAO, 2014). Barley is known as the "king of grains" in Ethiopia accounting about $5 \%$ of the per capita calorie consumption as a main ingredient in staple foods and local drinks. It is also used as substitute for other cereals in the country and serves as a roof thatch for many households (CSA, 2014).

In Ethiopia, barley is found to have experienced the highest annual fluctuation in area and yield. At the national level from the total area of cereals allocated in hectare, barley covered only $14.65 \%$ with the yield of 10.42 quintal per hectare. The total yield of barley has been increased by $5.2 \%$ between $2014 / 15$ to the year 2015/16 (CSA, 2016).

The Ethiopian Agriculture is characterized by low productivity which is attributed to different factors (WFP, 2010). Despite the large share of smallholder farmers in agricultural output in the country, they still practicing traditional production technology and using limited modern inputs (WB, 2007). Therefore, improving crop production and productivity is not an issue of preference rather than a must to achieve food security and hence poverty reduction.

According to FAO (FAO, 2011) the average cereal yield for the world and least developing countries were 37.08 and $20.19 \mathrm{qt} / \mathrm{ha}$, respectively, while, the average cereal yield in Ethiopia was limited to $17.60 \mathrm{qt} / \mathrm{ha}$.

Ethiopia is the largest malt barley producer in Sub-Saharan Africa and has a favorable malt barley growing climatic environment. It is primarily grown by subsistence farmers under rain-fed conditions. Although Ethiopia is the largest malt barley producer in Sub-Saharan Africa, it is reliant on foreign malt barley imports to satisfy its annual domestic demand (FAO, 2014). Malt barley is cultivated in the highlands of Ethiopia, mainly in Oromia, Amhara, Southern Nations and Nationalities Peoples and it is the most important cereal crop in Arsi zone, especially Tiyo district.

There is still yield gap between the output obtained from research stations and farmer's field. There are several factors believed to contribute to the low yield including moistures stress, shortage of seeds for improved varieties, degradation of soil fertility, insect pests, diseases and weeds. Previous researches in Ethiopia indicated that there was a broad cereal yield gap among the farmers that might be attributed to many factors such as lack of knowledge and information on how to use new crop technologies, poor management and climate factors (Sisay et al., 2015; Mesay et al., 2013).

Despite the importance of malt barley as a food and industrial crop, its productivity remains far below its potential (CSA, 2013a). Given the existing technology, improvements in the technical efficiency will enable farmers to produce the maximum possible output from a given level of inputs. Hence, improvements in the level of technical efficiency will increase productivity.

Researches on technical efficiency of smallholder agriculture are not extensive, and the conclusion of some of them is not consistent with one another. Therefore, policy inference strained from some observed works may not permit in 
scheming area specific strategies to be attuned with its socio-economic as well as agro-ecologic circumstances.

Therefore, from the perspective of making successful agricultural policies, improving farm level technical efficiency has a supreme significance in providing valuable information to policy makers which will be used to boost agricultural productivity. This study aims to analyze the technical efficiency of the smallholder farmers' ant its determinants in the study.

\section{Research methodology}

This study was conducted in Tiyo district, Arsi zone due to the production potential of malt barley. Arsi zone shares boundaries with East Shewa, West Hararghe, Bale zones and Southern People Nations and Nationalities Regional State. Assela is the zonal capital, located at $175 \mathrm{~km}$ south east of Addis Ababa.

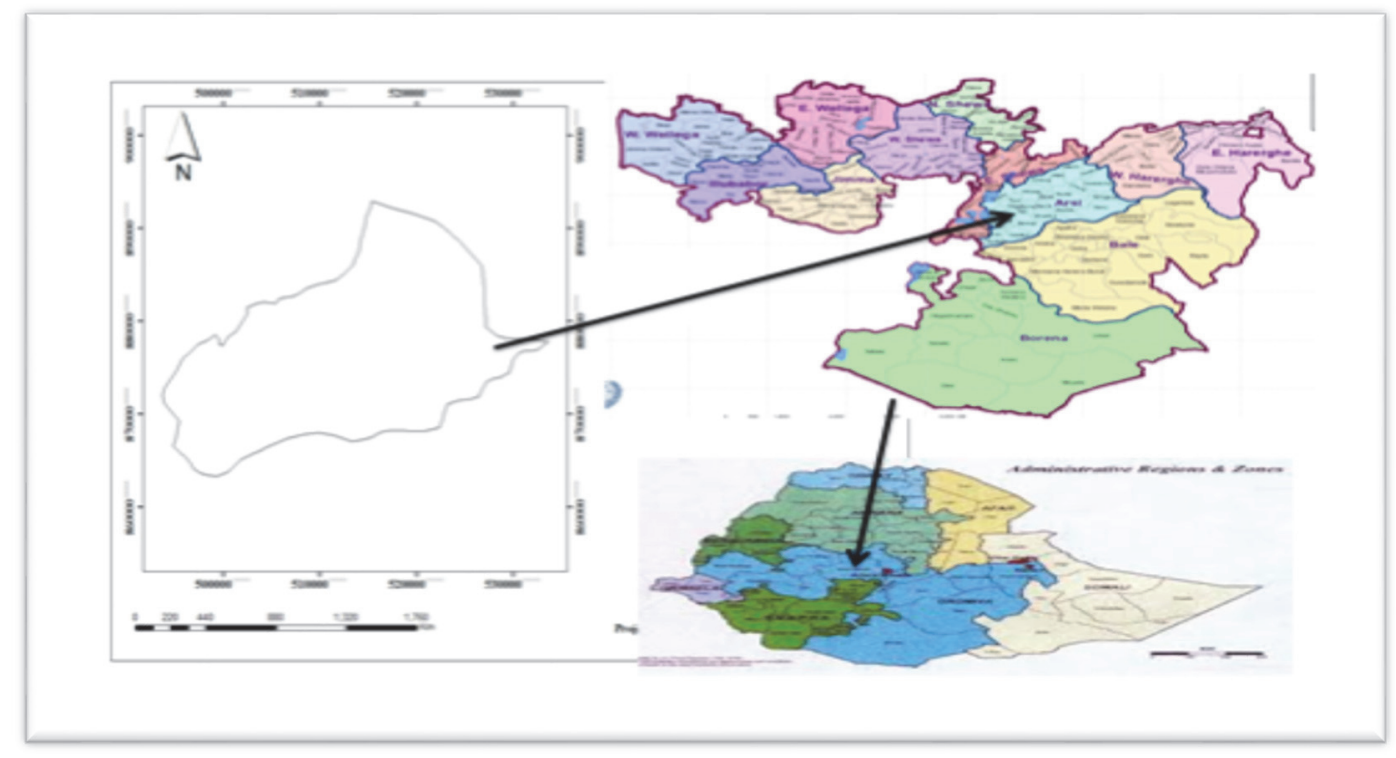

Figure. Location of Tiyo district in Arsi zone

Source: GIS output.

Tiyo district is one of the 24 districts of Arsi zone, Oromia regional state. It is located at $6^{\circ} 59^{\prime}$ to $8^{\circ} 49^{\prime} \mathrm{N}$ latitudes and $38^{\circ} 41^{\prime}$ to $40^{\circ} 44^{\prime}$ E longitudes. The farming system of Arsi zone is characterized by crop-livestock mixed farming system. Crop production is carried out in both meher and belg seasons although the main cropping season is meher. Malt barley, wheat, teff, maize, sorghum, faba bean, field peas, lentil, and linseed are the major annual crops grown in the zone.

Crop production is mainly practiced under rain-fed conditions. According to information from district agricultural office, cereals account for $80 \%$ of the land covered by crops. The major crops grown and average yields per hectare in the district for barley, wheat and teff are 11, 10 and 6 quintals respectively. 


\section{Data types, sources and methods of data collection}

Both primary and secondary data sources were used. The primary data was collected from sample households using a structured questionnaire that was administered by the trained enumerator. Secondary data was collected from local administration offices, governmental and non-governmental organizations, published and unpublished documents and central statistical agency which were used as additional information to strengthen the primary information provided by the sample households in the study area.

Methods of data analysis. Data were analyzed using descriptive statistics and econometric models.

Descriptive analysis. This was used to summarize and analyze the sample households socio-economic, demographic and institutional characteristics, used in the frontier production and in the efficiency model.

\section{Variables definition}

\section{Production function variables}

Output. This is dependent variable defined as the actual quantity of malt barley produced and measured in quintals during the 2016/17 production year.

Seed. This refers to the quantity of malt barley seed used in kilogram $(\mathrm{kg})$ by each household.

Land size. The amount of land used for malt barley production during 2016/17 production measured in hectares.

Fertilizers (Urea and DAP). This refers the total amount of Urea and DAP used in $\mathrm{kg}$ for the malt barley production in 2016/17 production year.

Labour. This input captures family, exchange and hired labour used for different agronomic practices of malt barley production in the 2016/17 production season.

Number of oxen. The number of oxen used for malt barley production.

Herbicide. This is the total expenditure of the farmer on herbicide purchase for malt barley production and measured in Ethiopian birr.

\section{Efficiency variables}

Age. This refers to age of the household head measured in years. It was expected that farmers with more years of experience are expected to be more efficient in malt barley production (Gosa, Jema, 2016).

Educational status. It is a continuous variable measured in years of schooling of the household head. Farmers with more years of formal schooling tend to be more efficient, most probably due to their improved ability to obtain practical knowledge, which makes them closer to the frontier (Jema, 2008; Mustefa, 2017).

Family size. It is a continuous variable which was defined as the total number of people living with the household. Family size could have a positive effect in raising the farmer's production efficiency (Musa et al., 2015; Sisay et al., 2015).

Livestock holding. It is a continuous variable which is the total number of livestock owned by farmers measured in terms of Tropical Livestock Unit (TLU). According to the study (Tiruneh, Geta, 2016; Mustefa, 2017) livestock holding were found to positively affect efficiency. 
Land size. It is a continuous variable measured hectare. Because of improper input usage and managing skill farmers who cultivated large farms are less efficient than the other (Sisay et al., 2015; Saulos, 2015). This was hypothesized that farm size negatively affects the efficiency of malt barley producers in the study area.

Non-farm activity. It is a dummy variable which takes a value 1 if the household members participate in nonfarm activity and 0 , otherwise. According to Kifle et al. (2017), participation in non-farm activity could have positive effect on efficiency. This was hypothesized that participation in non-farm activity positively affects the efficiency of malt barley producers in the study area.

Credit. It is a dummy variable which takes a value 1 when the household uses credit for agricultural reason and 0, otherwise. This was hypothesized that farmers who have used credit were more efficient than others (Musa et al., 2015; Kifle et al., 2017).

Market distance. This is the distance between a household home and the nearest market center measured in $\mathrm{km}$. It was hypothesized that the distance from the market place is negatively related to efficiency (Musa et al., 2015).

Extension contact. This is a continuous variable measured by the frequency of contacts made by development agents in relation to malt barley production with the farmers. It was hypothesized that a high frequency of contact with the development agent positively affects efficiency (Assefa et al., 2016).

Land disintegration. This is defined as the number of plots that the farmer has managed during the production season. Land disintegration leads to inefficiency by creating a shortage of family labour, costing time and other resources (Wondimagegn, 2010).

Soil fertility. This was measured as a dummy variable that takes a value of 1 if a household perceives his/her land as fertile and 0 , otherwise. This was hypothesized that a farmer who allocated a fertile land for malt barley production was more efficient than counterparts (Hika, Jema, 2016).

Sex. This is a dummy variable that takes a value of 1 if the household head is male and 0 , otherwise. It is hypothesized that male-headed households are more efficient than female-headed households in malt barley production (Fantu et al., 2011).

\section{Results and discussions}

Demographic and socio-economic characteristics of sample households. Average age of sample household heads was 46.54 years. The average family size of the sampled household heads was 7.36 with the standard deviation of 2.16. This big family size attached with small land size and traditional production system created difficulty for the farmers in their livelihood.

Education enhances the acquisition and utilization of information on improved technologies by farmers as well as their innovativeness. Education together with increased experience could direct farmers to better management skills. The educational level of the household head, on average, was 5.17 years. 
Socio-economic characteristics of sample households

\begin{tabular}{lcc}
\hline \multicolumn{1}{c}{ Variables } & Mean & Standard deviation \\
\hline Age (years) & 46.54 & 11.00 \\
Education status (grade) & 5.17 & 3.27 \\
Family size (number) & 7.36 & 2.16 \\
Land size (ha) & 2.42 & 1.05 \\
Number of oxen & 3.40 & 1.27 \\
Market distance (km) & 76.48 & 62.68 \\
Annual farm income (1000 ETB) & 41.67 & 22.82 \\
Annual non-farm income (1000 ETB) & 3.50 & 9.46 \\
\hline
\end{tabular}

Source: Authors computation (2016).

Potential crops grown in the study area. Wheat, maize, sorghum, teff, finger millet, barley, and bean are the major crops grown in the study area.

Yield of the major crops in the study area

\begin{tabular}{ccc}
\hline Crops grown & $\begin{array}{c}\text { Production (Qt) } \\
\text { Mean }\end{array}$ & $\begin{array}{c}\text { Land allocated (ha) } \\
\text { Mean }\end{array}$ \\
\hline Wheat & 26.13 & 0.88 \\
Sorghum & 7.16 & 0.43 \\
Teff & 4.35 & 0.26 \\
Finger millet & 2.60 & 0.13 \\
Maize & 18.73 & 0.61 \\
Malt barley & 17.36 & 0.67 \\
Bean & 1.70 & 0.17 \\
\hline
\end{tabular}

Source: Authors computation (2016).

Summary of variables used to estimate production function

Table 3

Descriptive statistics of both input and output variables

\begin{tabular}{lcccc}
\hline \multicolumn{1}{c}{ Variables } & Minimum & Maximum & Mean & Standard deviation \\
\hline Family size (number) & 2 & 14 & 5.80 & 9.82 \\
Area (ha) & 0.12 & 2.30 & 0.80 & 1.30 \\
Oxen & 1 & 16 & 2.80 & 3.56 \\
Output (quintal) & 3 & 51 & 14.74 & 8.90 \\
Seed (kg) & 15 & 200 & 60.23 & 18.62 \\
DAP (kg) & 30 & 250 & 60.22 & 17.16 \\
Urea (kg) & 15 & 150 & 42.60 & 16.00 \\
Herbicide(birr) & 35 & 280 & 122.30 & 34.51 \\
\hline
\end{tabular}

Source: Authors' computation (2016). 
Econometric model results. The model result showed that, from the six variables considered in the production function, four inputs (land, seed, oxen, and labour) had a significant effect in explaining the variation in malt barley yield among sampled farmers. When there is a $1 \%$ increase in the area of land, seed, oxen and labour allocated for malt barley production, mat barley yield would increase by $0.29,0.22,0.18$ and $0.19 \%$ respectively. This is consistent with the finding of Mustefa (2014). The diagnostic statistics of inefficiency reveals that sigma squared $\left(\delta^{2}\right) 0.283$ was statistically significant at $1 \%$ indicating the goodness of fit and the accuracy of the distributional form assumed for the composite error term.

Efficiency score of malt barley producers in the study area. The model results revealed that there were great differences in technical efficiency among smallholder malt barley farmers in the study area. The mean technical efficiency of sampled farmers was found to be $71 \%$. This shows that malt barley farmers have an opportunity to efficiently utilize resources and hence could increase the current malt barley output by $29 \%$ using the existing technology.

Table 4

Summary statistics of efficiency score of sample households

\begin{tabular}{ccccc}
\hline Variable & Mean & Standard Deviation & Minimum & Maximum \\
\hline TE & 0.711 & 0.211 & 0.241 & 0.942 \\
\hline
\end{tabular}

Source: Authors computation (2016).

Determinants of efficiency in malt barley production. To identify the technical efficiency status which was derived from stochastic frontier were regressed on factors that were hypothesized to affect efficiency levels using Tobit model. The results of the Tobit regression model showed that among the hypothesized variables five variables namely education status, family size, soil fertility status, extension contact and credit utilization were found to be statistically significant in determining the producers' level of technical efficiency in the study area.

Tobit model results of determinants of technical efficiency

Table 5

\begin{tabular}{lcc}
\hline \multicolumn{1}{c}{ Variable } & \multicolumn{2}{c}{ Technical efficiency } \\
\hline Age (years) & Coefficient & Standard Error \\
Education status (grade) & 0.122 & 0.0214 \\
Family size (number) & $0.071^{* * *}$ & 0.0143 \\
Livestock holding (TLU) & $0.213^{*}$ & 0.0072 \\
Soil fertility (dummy) & -0.162 & 0.0018 \\
Sex (1 = male, 0 = otherwise) & $0.063^{* *}$ & 0.0548 \\
Cultivated land (ha) & -0.072 & 0.0152 \\
Extension contact (number per month) & 0.031 & 0.0217 \\
Credit utilization & $0.082^{* * *}$ & 0.0100 \\
Non-farm income & $0.055^{* * *}$ & 0.0196 \\
Distance from market & 0.087 & 0.0321 \\
Constant & -0.022 & 0.0215 \\
\hline
\end{tabular}

Note: * ${ }^{* \star}$ and ${ }^{* \star *}$ significant at 10,5 and $1 \%$ level of significance respectively.

Source: Authors' computation (2016). 
The education status was positively and significantly affected technical efficiency at $1 \%$. This implies that more educated farmers are more technically efficient than those who have relatively less level of education. Besides, one-year increase in educational status of the household head increases the probability of the farmer being technically efficiency by $7.1 \%$.

The coefficient of family size is positive and statistically significant at the $10 \%$ significance level. The result implies that farmers with large family size are more efficient than farmers having small family size because family labour is the main input for crop production. This result is similar to the findings of S. Deme et al. (2015).

The result also reveals that soil fertility was positively and significantly related to technical efficiencies at 5\% level of significance. This implies that farmers who have allocated fertile land for malt barley production were more technically efficient than their counterparts. Similar result was reported by A.E. Awol (2014).

Frequency of extension contact also found to be significant at $1 \%$ level of significance. Farmers who had more contacted with extension workers during the production period were technically more efficient than their counterparts.

\section{Conclusion and recommendations}

The stochastic frontier Cobb - Douglas production function depicted that the amount of fertilizers, number of oxen, herbicides and land allocated for malt barley significantly determined production level of malt barley. The mean technical efficiency level of $71 \%$ indicates that production can be increased by $29 \%$. The stochastic production frontier model show that age, education status, land ownership, soil fertility, and frequency of extension contact have negative and land disintegration has positive and significant influence on the inefficiency of farmers.

The government has to give due attention for strengthening both formal and informal education using the existing infrastructural facilities like extension agents and Farmers Training Centers.

Development programs need to strengthen land management practices to progress and maintain the fertility of soil to increase efficiency of farmers. Given the existing technology, enhancing the advisory services of extension agents to the malt barley producers can improve the technical efficiency. The commitment of extension workers are highly appreciated an expected in the study area.

\section{References}

Assefa A., Jema H., Bosena T. (2016). Technical Efficiency of Smallholder Wheat Production in Soro District of Hadiya Zone, Southern Ethiopia. M.Sc. thesis presented to the School of Graduate Studies of Haramaya University, Ethiopia.

Awol A.E., (2014). Economic Efficiency of Rain-Fed Wheat Producing Farmer's in North Eastern Ethiopia: The Case of Albuko District. M.Sc. thesis presented to the School of Graduate Studies of Haramaya University, Ethiopia.

CSA (Central Statistical Agency). (2013). Agricultural sample survey 2012/2013 (2005 E.C.): Volume I. Report on area and production of major crops (Private peasant holdings, Meher season). Statistical Bulletin 532. Central Statistical Agency, Addis Ababa, Ethiopia. 
CSA (Central Statistical Agency). (2016). Agricultural sample survey report on area, production and farm management practice of Belg season crops for private peasant holdings (p. 5).

CSA (Central Statistics Agency). (2014). Annual Statistics Bulletin: Addis Ababa, Ethiopia.

Deme S., Matthews N., Henning, J. (2015). Analysis of factors affecting technical efficiency of smallholder maize farmers in Ethiopia. Conference Paper.

Fantu N., Berhane G., Asrat S., Getachew G., Taffesse A.S., Hoddinott J., (2011). Sources of inefficiency and growth in agricultural output in subsistence agriculture: a stochastic frontier analysis.

FAO (Food and Agricultural Organization). (2011). Food balance sheets database. http://faostat.fao.org (accessed: 09.09.2015).

FAO (Food and Agricultural Organization). (2014). Analysis of Price Incentives for Malt barley in Ethiopia for the time period 2005-2012. www.fao.org/fileadmin/templates/ .../Ethiopia/.../ethiopia_Malt barley_web.pd (accessed: 15.05.2015).

Gosa A., Jema H. (2016). Economic Efficiency of Sorghum Production for Smallholder Farmers in Eastern Ethiopia: The Case of Habro District. Journal of Economics and Sustainable Development, 7.

Hika W.F., Jema H. (2016). Economic Efficiency of Sesame Production in Babogambel District of West Wollega Zone, Oromia Region, Ethiopia. MSc thesis submitted to the School of Graduate Studies of Haramaya University.

Jema Haji. (2008). Economic efficiency and marketing performance of vegetable production in the eastern and central parts of Ethiopia. Doctoral Dissertation, Swedish University of Agricultural Sciences Uppsala.

Kifle D., Moti J., Belaineh L. (2017). Economic efficiency of smallholder farmers in maize production in Bako Tibe district, Ethiopia. Development Country Studies, 7(2).

Mesay Yami, Tesfaye Solomon, Bedada Begna, Fekadu Fufa, Tolesa Alemu, Dawit Alemu. (2013). Sources of technical inefficiency of smallholder malt barley farmers in selected water-logged areas of Ethiopia: A translog production function approach. African Journal of Agricultural Research, 8(29), 3930-3940.

Musa H., Lemma Z., Endrias G. (2015). Measuring technical, economic and allocative efficiency of maize production in subsistence farming: Evidence from the Central Rift Valley of Ethiopia. Applied Studies in Agribusiness and Commerce, 9(3), 63-74.

Mustefa Bati. (2017). Economic efficiency in barely production: The case of Chole district, East Arsi zone, Oromia National Regional State, Ethiopia. MSc thesis, Haramaya University, Haramaya, Ethiopia.

Ntabakirabose G. (2017). An economic analysis of the factors influencing maize productivity and efficiency in Gatsibo district, Rwanda. M.Sc. thesis presented to the School of Graduate Studies of Jomo Kenyatta University, Rwanda.

Saulos J.C. (2015). A survey on technical, allocative, and economic efficiency of maize production using the parametric stochastic frontier production function. African Journal of Agricultural Economics and Rural Development, 3(6), 237-245.

Sisay Debebe, Jema Haji, Degye Goshu, Abdi-Khalil Endriss. (2015). Technical, allocative, and economic efficiencies among smallholder maize farmers in southwestern Ethiopia: Parametric approach. Journal of Development and Agricultural Economics, 7(8): 282-291.

Solomon Bizuayehu. (2014). Technical efficiency of major crops in Ethiopia. M.Sc. Thesis, Oslo University, Oslo, Norway.

Tiruneh W.G., Geta E. (2016). Technical efficiency of smallholder wheat farmers: The case of Welmera district, Central Oromia, Ethiopia. Journal of Development and Agricultural Economics, 8(2), 39-51.

UNDP (United Nations development programme). (2018). Ethiopia's progress to warding eradicating poverty. Paper to be presented to the inter-agency group meeting on the implementation of the third United Nations decade for the eradication of poverty (2018-2027). Addis Abeba, Ethiopia. 
WB (World Bank). (2007). Project Performance Assessment Report: Seed System Development Project and National Fertilizer Sector project. Report No. 40124.

WFP (World Food Program). (2010). Summary of Food Security and Vulnerability in Selected Cities of Ethiopia.

Wondimagegn M. (2010). Analysis of Technical Efficiency of Wheat Production on Vertisol: The case of Enebsie Sar Mieir woreda in East Gojjam. M.Sc. Thesis presented to the School of Graduate Studies of Haramaya University, Ethiopia.

World Bank. (2013). World Development Report. World Bank, Washington, D.C, USA.

Article history:

Received: 19.08.2019

Revised: 05.09.2019

Accepted: 15.10.2019

\title{
For citation:
}

Bekele Y., Regasa G. (2019). Technical efficiency of smalholder malt barley producers in Tiyo district (Ethiopia). RUDN Journal of Economics, 27(3), 525-535. http://dx.doi.org/ 10.22363/2313-2329-2019-27-3-525-535

\section{Bio notes:}

Yadeta Bekele, lecturer and researcher, College of Agriculture and Veterinary Medicine, Jimma University. E-mail: yadeta11@gmail.com

Guta Regasa, student, College of Agriculture and Veterinary Medicine, Jimma University. E-mai: jiineguta2014@gmail.com

Научная статья

\section{Техническая эффективность малых производителей ячменного солода в районе Тийо (Эфиопия)}

\author{
Йядета Бекеле, Гута Регаса
}

\author{
Университет Джиммы \\ Федеративная Демократическая Республика Эфиопия, Клуж-Напока, \\ Почтовый офис, ящчик 37
}

Исследование посвящено оценке технической эффективности малых предприятий производителей ячменя на примере района Тийо (Эфиопия). Статистической базой послужили данные 162 производителей ячменя. Исследование показало, что средняя техническая эффективность производителей ячменя составляет 71 \%, при этом сохраняется возможность повысить уровень урожайности еще на 29 \% за счет уже существующих и используемых производителями технологий. Расчеты, проведенные авторами, показали, что коэффициент расхождения $(\gamma)$, оценивающий относительное отклонение выпуска от пограничного уровня из-за неэффективности, составил около $61 \%$. Исследование показало, что урожайность солодового ячменя находится в прямой зависимости от объема использованных удобрений, технической оснащенности, качества и количества посевного материала, площади использованных земель. Опыт наиболее эффективных фермеров может послужить хорошим примером для производителей с наимень- 
шей эффективностью и выпуском продукции. Наряду с этим государственная политика и меры в области улучшения технической составляющей фермерских хозяйств могут послужить дополнительным толчком для развития данной отрасли.

Ключевые слова: ячменный солод; техническая эффективность; стохастическая граница; производственная функция Кобба - Дугласа

\section{История статьи:}

Дата поступления в редакцию: 15.09.2019

Дата проверки: 25.09.2019

Дата принятия к печати: 17.10.2019

\section{Для цитирования:}

Bekele Y., Regasa G. Technical efficiency of smalholder malt barley pro-ducers in Tiyo district (Ethiopia) (Техническая эффективность малых производителей ячменного солода в районе Тийо (Эфиопия)) // Вестник Российского университета дружбы народов. Серия: Экономика. 2019. Т. 27. № 3. С. 525-535. http://dx.doi.org/10.22363/ 2313-2329-2019-27-3-525-535

\section{Сведения об авторах:}

Бекеле Йядета, преподаватель департамента экономики и управления сельским хозяйством, Колледж сельского хозяйства и ветеринарии, Университет Джиммы. E-mail: ya-deta11@gmail.com

Регаса Гута, старший преподаватель департамента экономики и управления сельским хозяйством, Колледж сельского хозяйства и ветеринарии, Университет Джиммы. E-mail: jiineguta2014@gmail.com 